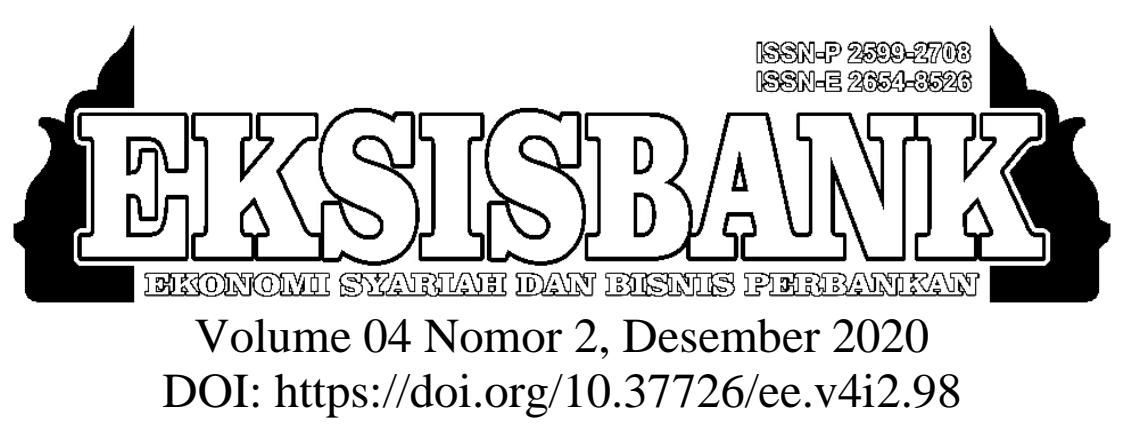

\title{
Keputusan Menjadi Nasabah Bank Muamalat KCP Purwakarta Ditinjau Dari Pengetahuan Calon Nasabah
}

\author{
Fitri Heryani ${ }^{1}$, Ahmad Damiri ${ }^{2}$, Jalaludin ${ }^{3}$ \\ ${ }^{1}$ Sekolah Tinggi Agama Islam (STAI) Riyadhul Jannah Subang \\ ${ }^{2}$ Universitas Islam Negeri Sunan Gunung Djati Bandung \\ ${ }_{3}^{3}$ Sekolah Tinggi Ilmu Ekonomi Syariah (STIES) Indonesia Purwakarta \\ ${ }^{1}$ fheryani205@gmail.com \\ 2ahmad.damiri86@gmail.com \\ 3 jalaludin@sties-purwakarta.ac.id
}

\begin{abstract}
ABSTRAK
Persepsi kebanyakan orang tentang bank syariah masih sangat dangkal, hanya sebatas mengetahui bahwa bank syariah tidak menggunakan bunga tetapi menggunakan sistem bagi hasil. Maka bank muamalat KCP Purwakarta dituntut untuk lebih meningkatkan edukasi tentang pengetahuan masyarakat terhadap bank syariah. Karena berdasarkan semakin tinggi pengetahuan seseorang tentang bank syariah, maka akan semakin tinggi pula kemungkinan untuk menggunakan Jasa bank syariah. Penelitian ini bertujuan untuk melihat sejauh mana pengaruh pengetahuan nasabah terhadap keputusan menjadi nasabah bank syariah $\mathrm{KCP}$ Purwakarta serta untuk mengetahui dan menganalisis bagaimana pengaruh dari ketiga dimensi bila diujikan secara bersama-sama (simultan) terhadap keputusan menjadi nasabah bank syariah KCP Purwakarta. Penelitian ini dilakukan pada nasabah bank syariah KCP Purwakarta, dengan sampel sebanyak 99 orang diambil secara random sampling. Menggunakan analisis deskriptif untuk menjelaskan data penelitian dan deskripsi penelitian, Jenis penelitian ini adalah metode kuantitatif. Variabel yang akan diteliti pada penelitian ini adalah pengaruh pengetahuan produk $\left(\mathrm{X}_{1}\right)$, pengetahuan pembelian $\left(\mathrm{X}_{2}\right)$, pengetahuan pemakaian $\left(\mathrm{X}_{3}\right)$ sebagai variabel bebas dan keputusan menjadi nasabah sebagai variable terikat (Y).Berdasarkan hasil analisis, penelitian dapat disimpulakan sebagai berikut: 1). Pengaruh X1 terhadap Y dengan nilai thitung $1,197<\mathrm{t}_{\text {tabel }} 1,985$, sehingga dapat menunjukan bahwa tidak terdapat pengaruh $\mathrm{X}_{1}$ terhadap $\mathrm{Y}$; 2). Pengaruh $\mathrm{X}_{2}$ terhadap $\mathrm{Y}$ dengan nilai thitung $-0,894<\mathrm{t}_{\text {tabel }} 1,985$, menunjukan bahwa tidak terdapat pengaruh $\mathrm{X}_{2}$ terhadap $\mathrm{Y}$; 3). Pengaruh $\mathrm{X}_{3}$ terhadap $\mathrm{Y}$ dengan nilai thitung $4,618>t_{\text {tabel }} 1,985$, menunjukan bahwa terdapat pengaruh $\mathrm{X}_{3}$ terhadap $\left.\mathrm{Y} ; 4\right)$. Pengaruh $\mathrm{X}_{1}, \mathrm{X}_{2}$
\end{abstract}

EKSISBANK (Ekonomi Syariah dan Bisnis Perbankan), Volume 4, Nomor 2, Desember 2020 
dan $\mathrm{X}_{3}$ terhadap $\mathrm{Y}$ dengan nilai $\mathrm{F}_{\text {hitung }}$ sebesar $7,451>\mathrm{F}_{\text {tabel }}$ 2,70 dengan nilai signifikansi (sig) $0,000<0,05$, menunjukan adanya pengaruh terhadap keputusan menjadi nasabah bank syariah (Bank Muamalat KCP Purwakarta). Pengaruh variabel $\mathrm{X}_{1}, \mathrm{X}_{2}$ dan $\mathrm{X}_{3}$ secara simultan terhadap Y adalah sebesar 19,0\%. Sedangkan sisanya merukapakan pengaruh dari faktor lain yang tidak diteliti oleh peneliti.

Kata kunci - Pengetahuan Produk, Pengetahuan Pembelian, Pengetahuan Pemakain.

\section{ABSTRACT}

The perception of most people about Islamic banks is still very shallow, only limited to knowing that Islamic banks do not use interest but use a profit sharing system. So the bank muamalat kcp purwakarta is required to further increase public knowledge about Islamic banks. The higher knowledge of Islamic banks makes the higher the possibility of adopting Islamic banks. This study aims to see the extent of the influence of customer knowledge (product knowledge (X1), purchasing knowledge (X2), usage knowledge (X3)) on the decision to become a customer of Islamic banks in Purwakarta and to know and analyze how the influence of the three variables when tested together (simultaneous) of the decision to become a customer of Islamic banks in Purwakarta. This research was conducted on Bank Muamalat KCP Purwakarta customers, with a sample of 99 people taken by random sampling. Using descriptive analysis to explain research data and research descriptions, this type of research is a quantitative method. The variables to be examined in this study are the influence of product knowledge (X1), purchasing knowledge (X2), usage knowledge (X3) as the independent variable and the decision to become customers as the dependent variable (Y).Based on the results of the analysis, the research can be summarized as follows: 1). The effect of X1 on $Y$ with a tcount 1.197<ttable 1.985, so it can show that there is no effect of X1 on $Y$; 2). The effect of $X 2$ on $Y$ with the tcount 0.894 <ttable 1.985, shows that there is no effect of X2 on $Y ; 3$ ). The influence of X3 on $Y$ with a tcount 4.618> ttable 1.985, shows that there is an influence of $X 3$ on $Y$; 4). The influence of X1, X2 and X3 on $Y$ with a Fcount 7.451> Ftable 2.70 with a significance value (sig) $0.000<0.05$, indicating an influence on the decision to become a customer of a Sharia bank (muamalat bank KCP Purwakarta). The influence of variables X1, $X 2$ and X3 simultaneously on $Y$ is $19.0 \%$. While the rest is the influence of other factors not examined by researchers.

Keywords - Product Knowledge, Purchasing Knowledge, Usage Knowledge.

\section{PENDAhUluan}

Indonesia merupakan Negara dengan mayoritas penduduknya yang beragama islam. Menurut data Badan Pusat Statistik (BPS) tahun 2020 berjumlah 263 juta jiwa, atau sekitar $13 \%$ dari populasi Muslim dunia. Dengan pertumbuhan besar seperti itu, Indonesia memiliki potensi untuk mengembangkan sistem perbankan syariah dengan lebih cepat. Dengan asumsi yang sederhana, apabila Indonesia memiliki jumlah penduduk muslim sebanyak 218.034.771 jiwa dan penduduk muslim Indonesia tersebut bersatu untuk menggunakan bank syariah, maka percepatan pertumbuhan perbankan syariah dapat dilakukan (FR., 2020). Dengan menggunakan pendekatan emosional saja, bank syariah dapat mengajak konsumen muslim bank konvensional berpindah ke bank syariah. Hal ini dapat terjadi jika konsumen muslim sadar akan ikatan emosionalnya dengan islam. Akan tetapi pada kenyataannya

EKSISBANK (Ekonomi Syariah dan Bisnis Perbankan), Volume 4, Nomor 2, Desember 2020 
tidak semudah itu, banyak konsumen muslim masih menggunakan pendekatan rasional untuk memilih bank. Hal ini dapat dilihat dari hasil penelitian yang dilakukan pada tiga wilayah (jawa barat., tengah, timur) oleh Bank Indonesia dari penelitian tersebut terungkap bahwa 95\% responden berpendapat bahwa sistem perbankan sangat penting dan dibutuhkan dalam mendukung kelancaran transaksi ekonomi.

Penelitian tersebut juga mengungkapkan bahwa kesan umum yang ditangkap oleh masyarakat tentang bank syariah adalah: (1) bank syariah identik dengan sistem bagi hasil, (2) bank syariah adalah bank yang islami. Namun berdasarkan survey yang dilakukan di wilayah Jawa Barat $8,1 \%$ reponden yang menyatakan bahwa bank syariah secara ekslusif hanya khusus untuk umat islam. Dari penelitian tersebut dapat disimpulkan bahwa pengetahuan konsumen tentang bank syariah yang relatif rendah karena hanya mengetahui hal-hal yang umum tentang bank syariah.

Penelitian ini penting untuk dilakukan atau di sajikan, karena Bank Muamalat KCP Purwakarta sangat jarang dikunjungi oleh nasabah, tidak seperti bank umum syariah lainnya yang setiap harinya bertumpuk antrian dari mulai layanan Customer service hinga setoran tunai atau penarikan tunai. Dan penelitian ini relatif baru, karena jarangnya penelitian berlokasi di Bank Muamalat KCP Purwakarta.

Penelitian ini akan dilakukan dengan empat tujuan penelitian, pertama mengetahui pengaruh pengetahuan produk terhadap keputusan menjadi nasabah bank Muamalat KCP Purwakarta, kedua mengetahui pengaruh pengetahuan pembelian terhadap keputusan menjadi nasabah bank Muamalat KCP Purwakarta, ketiga mengetahui pengaruh pengetahuan pemakaian terhadap keputusan menjadi nasabah bank Muamalat KCP Purwakarta, dan terakhir mengetahui pengaruh pengetahuan produk, pembelian, pemakain secara simultan terhadap keputusan menjadi nasabah bank syariah.

\section{A. Pengetahuan Konsumen}

Mowen and Minor mendefinisikan pengetahuan konsumen sebagai "The amount of experience with and information about particular product or services a person has". Atau pengetahuan adalah sejumlah pengalaman dengan berbagai macam informasi tentang produk atau jasa tertentu yang dimiliki (J. C. Mowen \& Minor, 2008).

Sedangkan Engel et all. "at a general level, knowledge can be defined information stored within memory. The subset of total information relevant to consumers functioningin the marketplace is called consumer knowledge". Atau secara umum, pengetahuan dapat didefinisikan sebagai informasi yang tersimpan dalam ingatan. Himpunan bagian informasi total yang relevan dengan fungsi konsumen di dalam pasar disebut pengetahuan konsumen. Pengetahuan konsumen adalah semua informasi yang dimiliki konsumen mengenai berbagai macam produk atau jasa (Engel et al., 1994).

Pengetahuan konsumen terdiri dari informasi yang tersimpan di dalam ingatan pengetahuan konsumen. Para pemasar sangat tertarik untuk mengerti dan memahami pengetahuan konsumen. Informasi yang dipegang oleh konsumen tentang produk/jasa akan sangat mempengaruhi pola pembelian mereka. Menurut Philip Kotler yang dialih bahasakan oleh (Kotler, Phillip, dialih bahasakan oleh Hendra Teguh, 2000) menyebutkan: "Pengetahuan adalah suatu perubahan dalam perilaku suatu individu yang berasal dari pengalaman." Konsumen memiliki tingkatan pengetahuan produk yang berbeda, yang dapat dipergunakan untuk menerjemahkan informasi baru dan membuat pilihan keputusan (Yuliawan, 2011). 
Menurut (Peter, 1999) membagi pengetahuan menjadi 3 jenis pengetahuan produk yaitu :

1. Pengetahuan tentang karakteristik atau atribut produk/jasa.

2. pengetahuan tentang manfaat produk/jasa.

3. Pengetahuan tentang kepuasan yang diberikan oleh produk/jasa bagi konsumen (Syafitri \& Shofawati, 2015).

Semakin meningkatnya persaingan dalam dunia perbankan maka bank-bank Syariah mendorong untuk lebih berorientasi kepada konsumen atau nasabah. Untuk mendukung upaya tersebut diperlukan pengetahuan mengenai konsumen terutama perilakunya. Setidaknya ada dua alasan mengapa perilaku konsumen perlu dipahami. Pertama, dengan memahami konsumen akan menuntun pemasar kepada kebijakan pemasaran yang tepat dan efisien. Kedua, diharapkan dengan berorientsi kepada konsumen, pemasar dapat melakukan strategi yang baik dalam mensiasati kelebihan penawaran dari pada permintaan di dunia bisnis.

Menurut (J. C. M. M. dialih bahasakan oleh L. S. Mowen, 2002) menjelaskan : "Perilaku konsumen adalah studi tentang unit pembelian dan proses pertukaran yang melibatkan perolehan, konsumsi, dan pembuangan barang/jasa, pengalaman serta ideide". Dalam engkonsumsi suatu produk, konsumen cenderung memilih produk yang memberikan nilai atau manfaat yang lebih dibandingkan dengan produk lainnya. Keputusan konsumen timbul karena adanya penilaian yang objektif atau karena dorongan emosi. Keputusan untuk bertindak adalah berasal dari serangkaian aktivitas dan rangsangan mental dan emosional. Keputusan yang rumit sering melibatkan beberapa keputusan (decision) melibatkan pilihan diantara dua atau lebih alternative. Keputusan selalu mensyaratkan pilihan diantara beberapa perilaku yang berbeda. Menurut (Nugroho, 2003) menjelaskan : "Keputusan pembelian konsumen adalah proses pengintegrasian yang mengkombinasikan pengetahuan untuk mengevaluasi dua atau lebih perilaku alternatif, dan memilih salah satu diantaranya:

1. Pengenalan Masalah Konsumen merasakan adanya kebutuhan dan keinginan yang belum terpenuhi dan terpuaskan.

2. Pencarian Informasi Konsumen mencari informasi yang disimpan di dalam ingatan atau mendapatkan informasi yang relevan dengan kepuasan dari lingkungannya.

3. Evaluasi Alternatif Konsumen mengevaluasi pilihan berkenaan dengan manfaat yang diharapkan dengan menyempitkan pilihan hingga alternatif yang dipilih.

4. Keputusan pembelian Konsumen memilih altrnatif yang dipilih dan memutuskan pembelian.

5. Perilaku Pasca Pembelian Konsumen mengevaluasi apakah altenatif yang dipilih telah memenuhi kebutuhan dan harapan setelah digunakan

\section{B. Keputusan Pembelian}

Menurut Kotler keputusan membeli yaitu: "beberapa tahapan yang dilakukan oleh konsumen sebelum melakukan keputusan pembelian suatu produk" Menurut Kotler, keputusan pembelian adalah tindakan dari konsumen untuk mau membeli atau tidak terhadap produk (Kotler \& Keller, 2009). Dari berbagai faktor yang mempengaruhi konsumen dalam melakukan pembelian suatu produk atau jasa, biasanya konsumen selalu mempertimbangkan kualitas, harga dan produk sudah yang sudah dikenal oleh masyarakat Sebelum konsumen memutuskan untuk membeli, biasanya konsumen melalui beberapa tahap terlebih dahulu yaitu, (1) pengenalan masalah, (2) pencarian informasi. (3) evaluasi alternatif, (4) keputusan membeli 
atau tidak, (5) perilaku pascapembelian (Kotler \& Keller, 2009).

Berdasarkan definisi diatas disimpulkan bahwa keputusan pembelian adalah tindakan yang dilakukan konsumen untuk melakukan pembelian sebuah produk. Oleh karena itu, pengambilan keputusan pembelian konsumen merupakan suatu proses pemilihan salah satu dari beberapa alternatif penyelesaian masalah dengan tindak lanjut yang nyata. Setelah itu konsumen dapat melakukan evaluasi pilihan dan kemudian dapat menentukan sikap yang akan diambil selanjutnya.

\section{TINJAUAN PUSTAKA}

Beberapa penelitian telah diakukan mengenai keputusan menjadi nasabah Bank Syariah, Seperti penelitian yang dilakukan oleh (Munajim \& Anwar, 2016), (Maski, 2012) yang menyatakan bahwa tingkat pengetahuan masyarakat lebih cenderung kepada faktor keislaman yang ada pada Perbankan Syariah, mayoritas nasabah mengetahui tentang ciri keislaman pada Bank Syariah. Namun sangat sedikit yang mengetahui mengenai operasional Perbankan Syariah tersebut, masyarakat lebih mengutamakan nilai keislaman yang dimiliki bank tersebut. Kemudian keputusan nasabah untuk memilih perbankan syariah dipengaruhi oleh variabel karakteristik perbankan syariah, variabel pelayanan dan kepercayaan, variabel pengetahuan, dan variabel fisik bank. Variabel services and trust memiliki koefisien beta terbesar yang menunjukkan bahwa variabel tersebut memiliki variabel dominan dalam mempengaruhi preferensi nasabah untuk menyimpan uangnya di perbankan syariah.

Selanjutnya penelitian dilakukan oleh (Romdhoni \& Sari, 2018), (Rachmawati et al., 2020), (Nastiti et al., 2020) menyatakan bahwa religiusitas, pengetahuan perbankan, pengetahuan produk perbankan, pengetahuan layanan perbankan, dan berbagi pengetahuan berpengaruh terhadap preferensi penggunaan layanan perbankan syariah.

\section{METODOLOGI PENELITIAN}

Metode penelitian yang digunakan dalam penelitian ini adalah pendekatan kuantitatif dan sifat penelitian deskriptif analitis. Lokasi Penelitian bertempat di Bank Muamalat KCP Purwakarta. Populasi dalam penelitian ini adalah 15.000 nasabah. Teknik penentuan sampel menggunakan rumus slovin (Sugiyono, 2018), dengan tingkat standarisasi errornya $10 \%$, sehingga menghasilkan sampel sebanyakk 99 nasabah. Sumber data yang digunakan adalah data primer dan sekunder yaitu dengan teknik pengumpulan data kuisioner, wawancara dan studi kepustakaan. Alat analisis yang digunakan adalah software SPSS 16.0 for windows. Teknik analisis data dilakukan dengan uji asumsi klasik (normality, multikolinearitas, heteroskedastisitas dan autokorelasi) dan uji regresi linear berganda (uji t dan uji f).

\section{HASIL DAN PEMBAHASAN A. Karakteristik Responden}

Karakteristik responden berdasarkan jenis kelamin $45 \%$ responden berjenis kelamin laki-laki dan $55 \%$ responden dari perempuan. Untuk lebih jelasnya bisa dilihat pada diagram dibawah ini.

\section{Diagram 4.1}

Responden Berdasarkan jenis kelamin

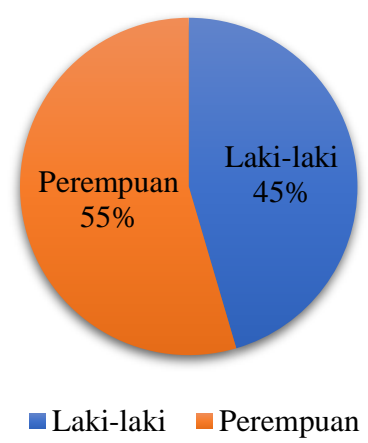

Sumber : diolah oleh Peneliti 
Grafik 4.1

Responden berdasarkan Usia

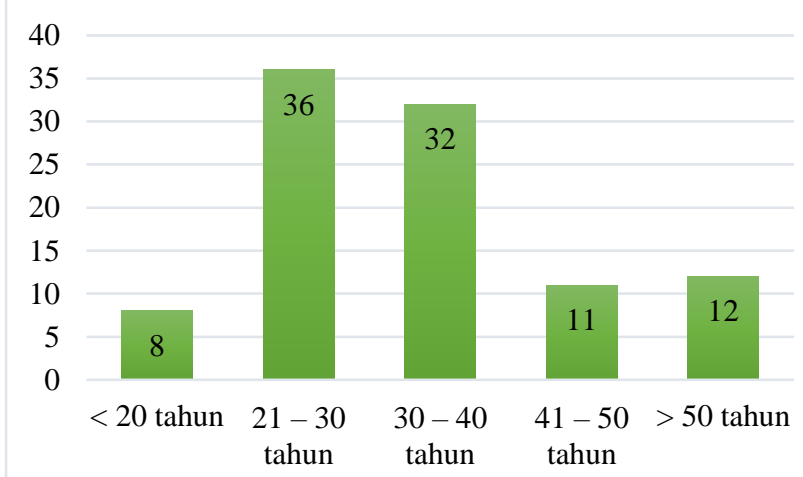

Sumber : diolah oleh Peneliti

Grafik 4.2

Responden Berdasarkan Jenis Pekerjaan

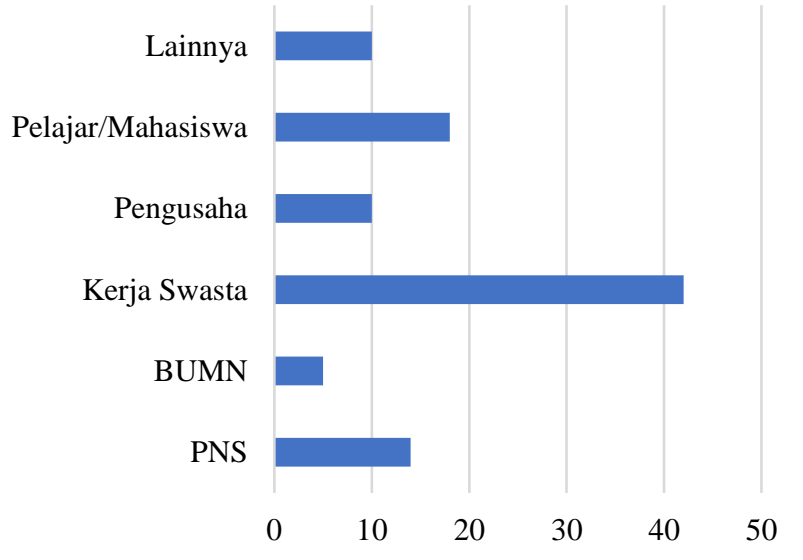

Sumber : Diolah Oleh Peneliti

Grafik 4.3

Responden Berdasarkan Sumber Informasi

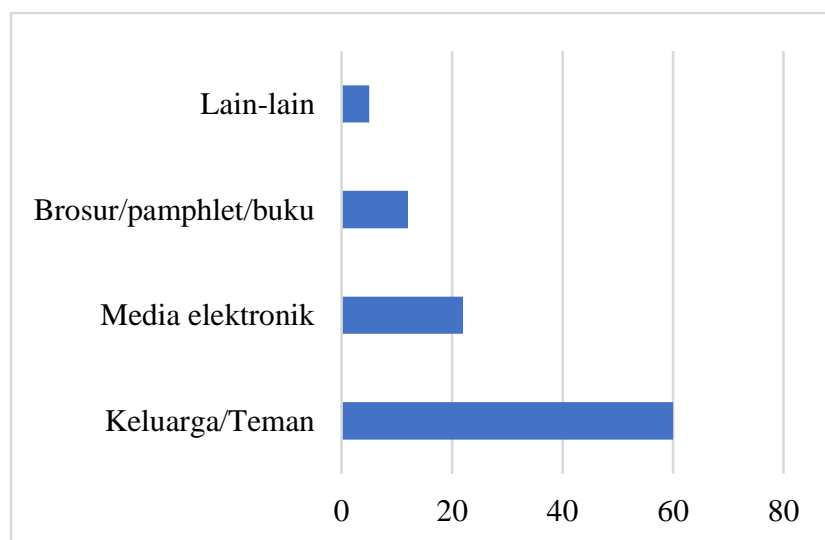

Sumber: Diolah Oleh Peneliti
Grafik 4.3

Responden Berdasarkan Lamanya Menjadi Nasabah

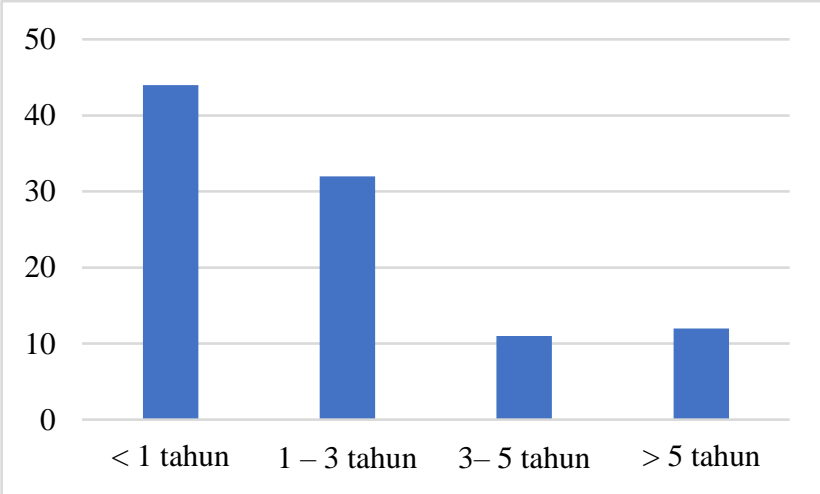

Sumber : Diolah Oleh Peneliti

\section{B. Uji T (Uji Parsial)}

Uji t dilakukan untuk mengetahui pengaruh masing-masing atau secara parsial variabel independent (pengetahuan produk, pengetahuan pembelian, pengetahuan pemakain) terhadap variabel dependen (keputusan menjadi nasabah bank syariah). Sementara itu secara parsial pengaruh dari ketiga variabel independent tersebut dapat dilihat pada tabel berikut ini:

Tabel 4.15

Hasil Pengujian Hipotesis Uji Parsial(Uji t )

\begin{tabular}{|c|c|c|c|c|c|c|}
\hline \multicolumn{7}{|c|}{ Coefficients $^{\mathrm{a}}$} \\
\hline & & \multicolumn{2}{|c|}{$\begin{array}{l}\text { Unstandardized } \\
\text { Coefficients }\end{array}$} & \multirow{2}{*}{$\begin{array}{c}\text { Standardized } \\
\text { Coefficients }\end{array}$} & \multirow[b]{2}{*}{$\mathrm{t}$} & \multirow[b]{2}{*}{ Sig. } \\
\hline \multicolumn{2}{|c|}{ Model } & B & Std. Error & & & \\
\hline \multirow[t]{4}{*}{1} & (Constant) & 19.045 & 3.937 & & 4.838 & .000 \\
\hline & Pengetahuan Produk $\left(\mathrm{X}_{1}\right)$ & .179 & .150 & .130 & 1.197 & .234 \\
\hline & Pengetahuan Pembelian $\left(\mathrm{X}_{2}\right)$ & -.150 & 168 & -.100 & -.894 & 374 \\
\hline & Pengetahuan Pemakaian $\left(\mathrm{X}_{3}\right)$ & .697 & 151 & .439 & 4.618 & .000 \\
\hline & ndent Variable: Keputusan me & ajadi nasa & ah bank Sya & & & \\
\hline
\end{tabular}

Sumber : Diolah Oleh Peneliti

Dasar pengambilan keputusan:

1.jika nilai sig. $<0,05$, atau nilai thitung > ttabel maka terdapat pengaruh variabel $\mathrm{X}$ terhadap variabel $Y$.

2.jika nilai sig. > 0,05, atau nilai thitung < ttabel maka tidak terdapat pengaruh variabel $\mathrm{X}$ terhadap variabel $\mathrm{Y}$.

$\mathrm{T}_{\mathrm{TABEL}}=\mathrm{T}(\mathrm{A} / 2 ; \mathrm{N}-\mathrm{K}-1)=\mathrm{T}(0,025 ; 95)=1,98$ 
Hasil dari tabel di atas dapat diuraikan sebagai berikut:

a. Diketahui nilai Sig. untuk pengaruh $\mathrm{X} 1$ terhadap Y adalah sebesar 0,234>0,05 dan nilai thitung $1,197<1,985$, sehingga dapat disimpulkan bahwa tidak terdapat pengaruh X1 terhadap Y.

b. Diketahui nilai Sig. untuk pengaruh $\mathrm{X} 2$ terhadap Y adalah sebesar 0,374 > 0,05 dan nilai thitung $-0,894<1,985$, sehingga dapat disimpulkan bahwa tidak terdapat pengaruh X2 terhadap Y.

c. Diketahui nilai Sig. untuk pengaruh X3 terhadap Y adalah sebesar $0,000<0,05$ dan nilai thitung 4,618 >1,985, sehingga dapat disimpulkan bahwa terdapat pengaruh X3 terhadap $\mathrm{Y}$.

\section{Uji F (Uji Simultan)}

Uji statistik $F$ pada dasarnya menunjukan apakah semua variabel independent yang dimasukan dalam model mempunyai pengaruh secara bersama-sama terhadap variabel dependennya.hasil perhitungan uji $\mathrm{F}$ dapat dilihar dari tabel berikut ini:

Tabel 4.16

Hasil Uji Statistik F

\begin{tabular}{|l|l|r|r|r|c|c|}
\hline \multicolumn{7}{|l|}{ ANOVA $^{\text {b }}$} \\
\hline \multirow{2}{*}{ Model } & Sum of Squares & df & Mean Square & \multicolumn{1}{c|}{ F } & \multicolumn{1}{c|}{ Sig. } \\
\hline 1 & Regression & 427.268 & 3 & 142.423 & 7.451 & $.000^{\mathrm{a}}$ \\
\cline { 2 - 7 } & Residual & 1815.843 & 95 & 19.114 & & \\
\cline { 2 - 7 } & Total & 2243.111 & 98 & & & \\
\hline
\end{tabular}

Sumber : Diolah Oleh Peneliti

Dasar pengambilan keputusan:

1. Jika nilai sig. $<0,05$, atau nilai Fhitung > Ftabel maka terdapat pengaruh variabel $\mathrm{X}$ terhadap variabel $\mathrm{Y}$.

2. Jika nilai sig. > 0,05, atau nilai Fhitung < Ftabel maka tidak terdapat pengaruh variabel $\mathrm{X}$ terhadap variabel $\mathrm{Y}$.

$$
\mathrm{F}_{\text {tabel }}=\mathrm{F}(\mathrm{k} ; \mathrm{n}-\mathrm{k})=\mathrm{F}(3 ; 95)=2,70
$$

Dari hasil analisis dapat diketahui bahwa secara bersama-sama variabel independen memiliki pengaruh yang signifikan terhadap variabel dependen. Hal ini dapat dibuktikan dari Fhitung sebesar 7,451> Ftabel 2,70 dengan nilai signifikansi (sig) $0,000<0,05$, maka model regresi dapat digunakan untuk memprediksi keputusan menjadi nasabah bank Syariah atau dapat dikatakan bahwa pengetahuan produk, pengetahuan pembelian dan pengetahuan pemakain secara bersamasama (simultan) berpengaruh terhadap keputusan menjadi nasabah bank Syariah (bank muamalat KCP Purwakarta).

Tabel 4.17

Koefisien Diterminasi

\begin{tabular}{|c|c|c|c|c|}
\hline \multicolumn{5}{|c|}{ Model Summary } \\
\hline Model & $\mathrm{R}$ & R Square & Adjusted R Square & $\begin{array}{l}\text { Std. Error of the } \\
\text { Estimate }\end{array}$ \\
\hline 1 & $.436^{\mathrm{a}}$ & .190 & .165 & 4.37197 \\
\hline
\end{tabular}

Sumber: Diolah Oleh Peneliti

Berdasarkan output diatas diketahui nilai $\mathrm{R}$ Square sebesar 0,190, hal ini mengandung arti bahwa pengaruh variabel $\mathrm{X} 1, \mathrm{X} 2$ dan $\mathrm{X} 3$ secara simultan terhadap $\mathrm{Y}$ adalah sebesar $19,0 \%$.

\section{Pembahasan}

Pembahasan dalam penelitian menguraikan pengaruh pengetahuan konsumen terhadap keputusan menjadi nasabah bank Syariah. Dimana pengetahuan konsumen meliputi: pengaruh pengetahuan produk, pengetahuan pembelian dan pengetahuan pemakaian terhadap keputusan menjadi nasabah bank Syariah.

1. Pengaruh Pengetahuan Produk, Pembelian, Pemakaian Terhadap Keputusan Menjadi Nasabah Bank Syariah

Dari hasil analisis dapat diketahui bahwa secara bersama-sama variabel independen memiliki pengaruh yang signifikan terhadap variabel dependen. Hal ini dapat dibuktikan

EKSISBANK (Ekonomi Syariah dan Bisnis Perbankan), Volume 4, Nomor 2, Desember 2020 
dari Fhitung sebesar 7,451 > Ftabel 2,70 dengan nilai signifikansi (sig) $0,000<0,05$, maka model regresi dapat digunakan untuk memprediksi keputusan menjadi nasabah bank Syariah atau dapat dikatakan bahwa pengetahuan produk, pengetahuan pembelian dan pengetahuan pemakain secara bersamasama (simultan) berpengaruh terhadap keputusan menjadi nasabah bank Syariah (bank muamalat KCP Purwakarta).

Berdasarkan output dari koefisien diterminasi diketahui nilai R Square sebesar 0,190, hal ini mengandung arti bahwa pengaruh variabel $\mathrm{X} 1, \mathrm{X} 2$ dan $\mathrm{X} 3$ secara simultan terhadap Y adalah sebesar 19,0\%.

\section{Pengaruh Pengetahuan Produk Terhadap Keputusan Menjadi Nasabah Bank Syariah}

Dari hasil persamaan regresi diperoleh nilai koefisien regresi untuk pengetahuan produk sebesar 0,179, selain itu memiliki thitung = $1,197<$ ttabel $=1,985$, serta memiliki nilai $\mathrm{p}$ value $=0,234>0,05$, sehingga dapat dikatakan bahwa pengetahuan produk tidak mempunyai pengaruh secara signifikan terhadap keputusan menjadi nasabah bank Syariah. Hal ini menunjukan bahwa pengetahuan produk bukan salah satu faktor yang dapat mempengaruhi keputusan menjadi nasabah di bank muamalat KCP Purwakarta. Faktor lain juga bisa disebabkan karena Produk bank Syariah khususnya Bank Muamalat masih menggunakan bahasabahasa Syariah, dan berakibat bahwa pengetahuan produk dianggap tidak terlalu penting yang lebih penting adalah layanan Syariah yang ada di Bank Muamalat KCP. Purwakarta. Penelitian ini juga hasilnya berbalik arah dengan penelitian terdahulu yang dilakukan oleh (Nastiti et al., 2020; Rachmawati et al., 2020; Romdhoni \& Sari, 2018) yang mengatakan bahwa Pengatahuan berpengaruh signifikan terhadap Keputusan menjadi nasabah di Lembaga keuangan Syariah.

\section{Pengaruh Pengetahuan Pembelian Terhadap Keputusan Menjadi Nasabah Bank Syariah}

Dari hasil persamaan regresi diperoleh nilai koefisien regresi untuk pengetahuan pembelian sebesar $-0,150$, selain itu memiliki thitung $=-0,894<$ ttabel 1,985, serta memiliki nilai $\mathrm{p}$ value $=0,374>0,05$, sehingga dapat dikatakan bahwa pengetahuan pembelian tidak mempunyai pengaruh secara signifikan terhadap keputusan menjadi nasabah bank Syariah. Hal ini menunjukan bahwa pengetahuan pembelian bukan salah satu faktor yang dapat mempengaruhi keputusan menjadi nasabah di bank muamalat KCP Purwakarta. Faktor lain juga bisa disebabkan karena Produk bank Syariah khususnya Bank Muamalat masih menggunakan istilah-istilah arab, dan berakibat bahwa pengetahuan pembelian dianggap tidak terlalu penting, yang lebih penting adalah kebutuhan para nasabah bisa dipenuhi oleh Lembaga Bank Muamalat KCP. Purwakarta. Mereka tidak terlalu menghiraukan kegunaan dari setiap produk yang disediakan oleh Bank Muamalat KCP Purwakarta, yang mereka pikirkan lebih dominan terhadap tatacara pemenuhan kebutuhan Nasabah oleh pihak perbankan Syariah khususnya di Bank Muamalat KCP Purwakarta. Penelitian ini juga hasilnya berbalik arah dengan penelitian terdahulu yang dilakukan oleh (Nastiti et al., 2020; Rachmawati et al., 2020; Romdhoni \& Sari, 2018) yang mengatakan bahwa Pengatahuan berpengaruh signifikan terhadap Keputusan menjadi nasabah di Lembaga keuangan Syariah. 


\section{Pengaruh Pengetahuan Pemakaian Terhadap Keputusan Menjadi Nasabah Bank Syariah}

Dari hasil persamaan regresi diperoleh nilai koefisien regresi untuk pengetahuan pemakaian sebesar 0,697 , selain itu memiliki thitung $=4,618>$ ttabel 1,985 , serta memiliki nilai $\mathrm{p}$ value $=0,000<0,05$, dengan demikian dapat dikatakan bahwa terdapat pengaruh yang signifikan antara pengetahuan pemakaian terhadap keputusan menjadi nasabah bank Syariah.

Faktor lain juga bisa disebabkan karena Produk bank Syariah khususnya Bank Muamalat masih menggunakan istilah-istilah arab, dan berakibat bahwa pengetahuan pemakaian dianggap tidak terlalu penting, yang lebih penting adalah kebutuhan para nasabah bisa dipenuhi oleh Lembaga Bank Muamalat KCP. Purwakarta. Mereka tidak terlalu menghiraukan kegunaan dari setiap produk yang disediakan oleh Bank Muamalat KCP Purwakarta, yang mereka pikirkan lebih dominan terhadap tatacara pemenuhan kebutuhan Nasabah oleh pihak perbankan Syariah khususnya di Bank Muamalat KCP Purwakarta. Penelitian ini juga hasilnya berbalik arah dengan penelitian terdahulu yang dilakukan oleh (Nastiti et al., 2020; Rachmawati et al., 2020; Romdhoni \& Sari, 2018) yang mengatakan bahwa Pengatahuan berpengaruh signifikan terhadap Keputusan menjadi nasabah di Lembaga keuangan Syariah

Hasil pada penelitian ini sesuai dengan teori yang dikemukakan oleh (Engel et al., 1994). yang berpendapat bahwa konsumen dapat dipengaruhi perilakunya menurut kehendak pihak yang berkepentingan. Selanjutnya Engel juga menyebutkan sedikitnya ada tiga faktor yang menjadi deteminan variasi penentu keputusan konsumen. Salah satu dari factor tersebut adalah pengaruh individu yang termasuk di dalamnya adalah faktor pengetahuan. Dan menurut (Engel et al., 1994), pengetahuan konsumen dapat dibagi menjadi tiga, dan salah satunya adalah pengetahuan pemakaian.

\section{KESIMPULAN}

Dari rumusan masalah yang diajukan, analisis data yang telah dilakukan dan pembahasan yang telah dikemukakan pada bab sebelumnya, maka dapat ditarik kesimpulan sebagai berikut:

Hasil penelitian menunjukan Pengaruh Pengetahuan Produk (X1) Terhadap Keputusan Menjadi Nasabah Bank Syariah (Y), berdasarkan hipotesis pertama yang diajukan dalam penelitian ini bahwa, jika nilai probability $(p)>0,001 \mathrm{Ho}=$ diterima, Jika nilai probability $(\mathrm{p})<0,001 \mathrm{H} 1=$ ditolak. Dari tabel di atas terlihat bahwa $\mathrm{p}=0,234$ yang berarti lebih besar dari 0,05. Dengan demikian Ho diterima dan $\mathrm{H} 1$ ditolak atau dengan kata lain bahwa tidak terdapat hubungan yang signifikan antara pengetahuan produk dengan keputusan menjadi nasabah Bank Syariah.

Hal tersebut juga terjadi pada Pengaruh Pengetahuan Pembelian (X2) Terhadap Keputusan Menjadi Nasabah Bank Syariah (Y), berdasarkan hipotesis kedua yang diajukan (pengaruh X2 terhadap Y) dalam penelitian bahwa, jika nilai probability (p) > $0,001 \mathrm{Ho}=$ diterima, Jika nilai probability (p) $<0,001 \mathrm{H} 1=$ ditolak. Dari tabel di atas terlihat bahwa $\mathrm{p}=0,374$ yang berarti lebih besar dari 0,05. Dengan demikian Ho diterima dan H1 ditolak atau dengan kata lain bahwa tidak terdapat hubungan yang signifikan antara pengetahuan pembelian dengan keputusan menjadi nasabah bank syariah.

Demikian dengan Pengaruh Pengetahuan Pemakaian (X3) Terhadap Keputusan Menjadi Nasabah Bank Syariah (Y), telah diajukan hipotesis ketiga (pengaruh X3 terhadap Y) dalam penelitian ini bahwa, jika 
nilai probability $(\mathrm{p})>0,001 \mathrm{Ho}=$ diterima, Jika nilai probability $(\mathrm{p})<0,001 \mathrm{H} 1=$ ditolak. Dari tabel di atas terlihat bahwa $p=0,000$ yang berarti lebih kecil dari 0,05. Dengan demikian Ho ditolak dan $\mathrm{H} 1$ diterima atau dengan kata lain bahwa terdapat hubungan yang signifikan antara pengaruh pengetahuan pemakaian dengan keputusan menjadi nasabah bank syariah. Dari ketiga variabel yang diambil dalam penelitian ini hanya variabel X3 yang menunjukan adanya pengaruh yang signifikan terhadap keputusan menjadi nasabah bank Syariah (Y).

Adapun salah satu tujuan dalam penelitian ini adalah mengetahui Pengaruh Pengetahuan Produk (X1), Pengetahuan Pembelian (X2), Pengetahuan Pemakaian (X3) Terhadap Keputusan Menjadi Nasabah Bank Syariah (Y). berdasarkan hipotesis dasar pengambilan keputusan jika nilai probability $(p)>0,001 \mathrm{Ho}$ $=$ diterima, Jika nilai probability $(\mathrm{p})<0,001$ $\mathrm{H} 1=$ ditolak. Dari hasil penelitian menunjukan bahwa nilai $\mathrm{p}=0,000$ yang berarti lebih kecil dari 0,05. Dengan demikian Ho ditolak dan $\mathrm{H} 1$ diterima atau dengan kata lain bahwa terdapat hubungan yang signifikan antara Pengaruh pengetahuan produk, pengetahuan pembelian, pengetahuan pemakaian terhadap keputusan menjadi nasabah bank syariah.

Berdasarkan output dari hasil uji koefisien diterminasi diketahui nilai $\mathrm{R}$ Square sebesar 0,190, hal ini mengandung arti bahwa pengaruh variabel $\mathrm{X} 1, \mathrm{X} 2$ dan $\mathrm{X} 3$ secara simultan terhadap $Y$ adalah sebesar 19,0\%. Sedangkan sisanya merukapakan pengaruh dari faktor lain tidak diteliti.

\section{DAFTAR PUSTAKA}

Engel, F. J., Blackwell, R. D., \& Miniard, P. W. (1994). Perilaku Konsumen (6 Jilid 1 (ed.)). Binarupa Aksara.

FR., Y. (2020). Data Populasi Penduduk Muslim 2020: Indonesia Terbesar di
Dunia - IBTimes.ID. RedaksiIB. https://ibtimes.id/data-populasipenduduk-muslim-2020-indonesiaterbesar-di-dunia/

Kotler, Phillip, dialih bahasakan oleh Hendra Teguh, R. A. R. dan M. M. (2000). Manajemen Pemasaran (Bahasa Ind). PT Prenhallindo.

Kotler, P., \& Keller, K. L. (2009). Manajemen Pemasaran (Jilid 2 Ed). Erlangga.

Maski, G. (2012). Analisis Keputusan Nasabah Menabung Maski. In Journal of Indonesian Applied Economics (Vol. 4, Issue

https://jiae.ub.ac.id/index.php/jiae/article /view/120

Mowen, J. C. M. M. dialih bahasakan oleh L. S. (2002). Consumer Behavior (6th ed.). Pentice-Hall,Inc.

Mowen, J. C., \& Minor, M. (2008). Consumer Behavior (6th ed.). Prentice-Hall.

Munajim, A., \& Anwar, S. (2016). Faktor Yang Mempengaruhi Keputusan Menjadi Nasabah Bank Syariah. In Syntax Literate ; Jurnal Ilmiah Indonesia (Vol. 1, Issue 2).

https://doi.org/10.36418/SYNTAX-

LITERATE.V1I2.28

Nastiti, N., Hartono, A., \& Ulfah, I. F. (2020). Pengaruh Religiusitas, Pengetahuan Perbankan, Pengetahuan Produk Perbankan, Pengetahuan Pelayanan Perbankan, Dan Pengetahuan Bagi Hasil Terhadap Preferensi Menggunakan Jasa Perbankan Syariah. ASSET: Jurnal Manajemen Dan Bisnis, 1(1), 15-25. https://doi.org/10.24269/asset.v1i1.2554 Nugroho, S. J. (2003). Perilaku Konsumen. Andi.

Peter, J. P. and J. C. O. dialih bahasakan oleh D. S. (1999). Consumer Behavior and Marketing Strategy (4th ed.). The Mc Graww-Hill Companies.

Rachmawati, A., Studi, P., Syariah, E., \& 
Dahlan, A. (2020). Pengaruh Consumer Knowledge, Brand Image, Religiusitas, Dan Lokasi Terhadap Keputusan Menjadi Nasabah Pada Bank Syariah. Jurnal Ekonomi Syariah, 5(1).

Romdhoni, A. H., \& Sari, D. R. (2018). Pengaruh Pengetahuan, Kualitas Pelayanan, Produk, dan Religiusitas terhadap Minat Nasabah untuk Menggunakan Produk Simpanan pada Lembaga Keuangan Mikro Syariah. Jurnal Ilmiah Ekonomi Islam, 4(02), 136. https://doi.org/10.29040/jiei.v4i02.307 Sugiyono. (2018). Metode Penelitian Kuantitatif, Kualitatif, dan $R \& D$. Alfabeta.
Syafitri, D. P., \& Shofawati, A. (2015). Pengaruh Pengetahuan Produk Terhadap Keputusan Menjadi Donatur Baitul Maal Hidayatullah Cabang Kediri. Jurnal Ekonomi Syariah Teori Dan Terapan, 1(2), 128. https://doi.org/10.20473/vol1iss20142pp $128-143$

Yuliawan, E. (2011). Pengaruh Pengetahuan Konsumen Mengenai Perbankan Syariah Terhadap Keputusan Menjadi Nasabah pada PT. Bank Syariah Cabang Bandung. In Jurnal Wira Ekonomi Mikroskil: JWEM (Vol. 1, Issue 1). https://www.mikroskil.ac.id/ejurnal/inde x.php/jwem/article/view/53 